\title{
CAPIM-LIMÃO - Cymbopogon citratus (D.C.) Stapf: SUBSÍDIOS PARA MELHORIA DE QUALIDADE DO CULTIVO, INDUSTRIALIZAÇÃO E COMERCIALIZAÇÃO NO ESTADO DO PARANÁ
}

\author{
CAPIM-LIMÃO - Cymbopogon citratus (D.C.) STAPF: SUBSIDY TO \\ IMPROVMENT OF QUALITY IN THE CROP, INDUSTRIALIZATION AND \\ MARKETING IN PARANÁ STATE
}

\author{
Eliane C. GOMES ${ }^{1}$ \\ Orientadora: Raquel R. B. NEGRELLE²
}

Programa de Pós-graduação em Agronomia - Área de concentração em Produção Vegetal, Departamento de Fitotecnia e Fitossanitarismo, Setor de Ciências Agrárias, Universidade Federal do Paraná,

\section{RESUMO}

Considerando-se o mercado promissor para produtos naturais e sua crescente demanda, aliados à carência de conhecimentos em várias áreas, especialmente estudos que relacionam a qualidade aos segmentos da cadeia produtiva das espécies, esta tese teve como objetivo realizar estudos a respeito da qualidade de Cymbopogon citratus (D.C.) Stapf no cultivo, industrialização e comercialização, relacioná-los às suas possíveis causas e propor soluções aos agentes envolvidos na cadeia produtiva da espécie, no Estado do Paraná; visando subsidiar a melhoria do sistema como um todo. Este trabalho envolveu pesquisa de campo, entrevistas com produtores e outros agentes da cadeia de produção, além de diferentes análises laboratoriais de qualidade do produto bruto, beneficiado ou final disponível no mercado consumidor de Curitiba (2000-2003). Os resultados desta pesquisa compõe os 9 capítulos que integram a tese. Nos capítulos 1 e 2, apresenta-se uma vasta revisão de literatura englobando aspectos botânicos, ecológicos, fitoquímicos e farmacológicos do capim-limão, sendo o composto químico principal o aldeído citral, destacando-se as ações analgésica, antimicrobiana, inseticida e antitumoral da planta. No Capítulo 3, apresenta-se o estudo prospectivo da cadeia produtiva do capim-limão no Estado do Paraná, evidenciou como principais componentes desta cadeia: a unidade produtiva, a agroindústria, a indústria (química, alimentícia e farmacêutica), o comércio (atacadista e varejista) e o mercado consumidor (interno e externo). No Capítulo 4, um panorama detalhado dos procedimentos associados ao cultivo do capim-limão no Estado do Paraná, evidenciou as congruências e divergências dos dados de pesquisa de campo com o descrito na literatura como adequado para este tipo de cultura. No capítulo 5, trata-se das etapas de colheita e pós-colheita (beneficiamento, embalagem e armazenamento) do capim-limão praticados pelos produtores paranaenses, com vistas a subsidiar a oferta de um produto de boa qualidade. No capítulo 6, apresentam-se informações sobre embalagem e rotulagem das marcas de chá de capim-limão comercializadas pelo segmento supermercado na cidade de Curitiba, detectando-se 19 marcas. No capítulo 7 são apresentados os resultados de pesquisa exploratório-descritiva realizada no setor supermercadista visando avaliar a qualidade e adequabilidade do acondicionamento (embalagem) e local de armazenagem de chás frente à legislação vigente. Além disso, elaborou-se um instrumento base para incrementar a inspeção sanitária neste setor de comercialização. A pesquisa apresentada no Capítulo 8 visou avaliar 4 marcas de chá de capim-limão comercializadas na região metropolitana de Curitiba. no que concerne à qualidade microbiológica e físico-química, tendo como base a legislação brasileira do Ministério da Saúde para alimentos. Evidenciou-se a presença de bactérias como Escherichia coli, além de bolores e leveduras, com presença de Aspergillus niger em duas amostras. Não foi detectada Salmonella sp., nem aflatoxinas. No capítulo 9, sintetizando os diferentes problemas e gargalos evidenciados nos trabalhos anteriormente citados, é apresentado um conjunto de recomendações e propostas aos agentes econômicos que atuam e processam na cadeia produtiva do capim-limão no Estado do Paraná.

Palavras-chave: planta medicinal, cadeia produtiva, chá

\footnotetext{
${ }^{1}$ Universidade Federal do Paraná, Professora Adjunta do Departamento de Saúde Comunitária, R. Padre Camargo, 280- 7º andar. 80060-240. Curitiba, PR. E-mail: elianegomes@ufpr.br;

${ }^{2}$ Universidade Federal do Paraná, Professora Adjunta do Departamento de Botânica. E-mail: negrelle@ufpr.br
} 
GOMES, E.C. Capim-limão - Cymbopogon citratus...

\section{ABSTRACT}

Regarding the promising market of natural products and its crescent requires, associated with a lack of knowledge in various areas, particularing studies that relates the quality and segments of produtctive chain of all sorts of species, the objetive of this work was to realize studies about the quality of Cymbopogon citratus (D.C.) Stapf in the crop, industrialization and marketing, to link with its possible causes and to propose solutions to envolved agents in the productive chain of species, in Paraná State, aiming at to subsidy the improvement of the system in general. This work involved field research, interviews with producers and agents of productive chain, besides diferent laboratories analysis of quality of crude product, processed or final available to consumer market in Curitiba (20002003). The results of this research compose the nine chapters that integrate the thesis. The chapters 1 and 2 , introduce extensive revision of botanical, ecological, phytochemical and pharmacological aspects of lemon grass, were identified the main chemical compound as the aldehyde citral, and the main pharmacological actions were: analgesic, anti-microbial, insecticide and anti-tumor. The chapter 3 , results of the research to give subsidies for the comprehension of chain production of lemon grass in Paraná State. Identifyied as main components of the productive chain: the productive unit, the agroindustry, the industry (chemical, nutritive and pharmaceutical), the market (wholesale and retail) and the consumer ( interior and exterior). The chapter 4, a detailed view of proceedings associated to the crop in this State, evidencing the congruency and divergency of field research data and what is reported on literature as been suitable for this crop. The chapter 5 refers the harvest and postharvest (processing, package and storage) of lemon grass executed by producers of Paraná State, to give subsidies to the offer of good quality product. The chapter 6 introduces informations about packaging and labelling of lemon grass tea trademarks commercialized by supermarkets in Curitiba city, were evidenced nineteen trademark. The chapter 7 presents data from an explorative-descriptive research that took place in the supermarkets sector to evaluate the quality and adequability of packaging and storage areas of teas considering current legislation. Besides providing a general view about the situation of tea storage, this research had the purpose of creating a base instrument to develop the sanitary inspection in this sector of marketing. The research presented in chapter 8 aimmed to evaluate four lemon grass tea trademarks marketed in the metropolitan area of Curitiba, regarding their microbiology and physical-chemical quality based on the Brazilian Health Departament food legislation. Evidenced bacterial contamination with Escherichia coli and others, besides moulds and yeasts, with presence of Aspergillus niger in two samples. Salmonella $s p$ and aflatoxins were absent. The chapter 9 synthetizing the diferent problems and strangulations evidenced in the previously cited chapters, is presented a group of proposes and recommendations to the economic agents that act and carry in productive chain of lemon grass in Paraná State.

Key-words: medicinal plant, productive chain, tea. 